\title{
PEMBELAJARAN SEJARAH KEBUDAYAAN INDONESIA MELALUI MEDIA AUDIO VISUAL BERBASIS KEARIFAN LOKAL
}

\author{
Aulia Fitriany \\ STKIP PGRI Sidoarjo \\ auliafitriany28@gmail.com
}

\begin{abstract}
ABSTRAK
Penelitian ini untuk mengetahui perencanaan, pelaksanaan dan evaluasi pembelajaran Sejarah Kebudayaan Indonesia melalui media audio visual berbasis kearifan lokal. Penelitian ini dilakukan di kelas 2018 tahun akademik 2019/2020 Program Studi Pendidikan Sejarah STKIP PGRI Sidoarjo. Metode penelitian yang digunakan bersifat kualitatif deskriptif. Sumber data terdiri atas narasumber ketua program studi, dosen dan mahasiswa. Sumber dokumen berupa kurikulum, rencana pembelajaran semester, rancangan program perkuliahan, serta tempat dan aktivitas pembelajaran. Validitas data dilakukan dengan teknik trianggulasi sumber dan trianggulasi metode. Analisis data menggunakan model analisis interaktif yang meliputi reduksi data, sajian data, dan penarikan kesimpulan. Hasil penelitian ini : (1) Perencanaan pembelajaran dimulai dengan menyusun perangkat pembelajaran yang meliputi rencana pembelajaran semester dan rancangan program perkuliahan. Penggunaan media pembelajaran disesuaikan dengan kemampuan akhir yang diharapkan. (2) Pelaksanaan pembelajaran dilaksanakan dengan penyampaian materi pembelajaran dan pemberian penugasan membuat media secara berkelompok. (3) Evaluasi pembelajaran meliputi penilaian diskusi dan penilaian hasil penugasan.
\end{abstract}

Kata kunci: Sejarah Kebudayaan Indonesia, Media audio visual, Kearifan lokal

\section{ABSTRACT}

This study is to determine the planning, implementation and evaluation of Indonesian Cultural History learning through audio-visual media based on local wisdom. This research was conducted in class 2018 for the academic year 2019/2020 History Education Study Program STKIP PGRI Sidoarjo. The research method used is descriptive qualitative. Sources of data consisted of resource persons, the head of the study program, lecturers and students. The document sources are in the form of curriculum, semester learning plan, lecture program design, and learning places and activities. The data validity was done by using source triangulation technique and method triangulation. Data analysis used an interactive analysis model which included data reduction, data presentation, and conclusion drawing. The results of this study: (1) Learning planning begins with compiling learning tools which include Semester Learning Plans and Class Program Design. The use of learning media is adjusted to the expected final ability. (2) The learning process is carried out by delivering learning material and giving assignments to make media in groups. (3) Evaluation of learning includes assessment of discussion and assessment of assignment results.

Keywords: Indonesian Cultural History, Audio-visual Media, Local Wisdom 


\section{PENDAHULUAN}

Pembelajaran sejarah diharapkan dapat menumbuhkan wawasan peserta didik akan guna dari sejarah bagi kehidupan sehari-hari. Pembelajaran sejarah pada umumya adalah mengkaji peristiwa-peristiwa di masa lampau. Sejarah adalah penuh arti dan makna, sebab sejarah adalah ilmu yang mempelajari peristiwa kehidupan manusia pada masa lampau yang memiliki tugas pokok membuka kegelapan umat manusia pada masa lampau untuk dipaparkan pada generasi masa kini, dengan tujuan agar generasi masa kini dapat mengetahui, mamahami, dan mencontoh hal-hal yang positif dari generasi masa lampau (Daliman 2012).

Dalam sejarah terkandung beberapa aspek yang perlu kita pelajari, yaitu aspek pengetahuan, aspek sikap, dan aspek keterampilan. Aspek-aspek ini perlu dipelajari dalam proses belajar mengajar di sekolah. Hal ini akan bermanfaat bagi peserta didik dalam upaya memecahkan permasalahan yang dihadapi di dalam masyarakat pada masa yang akan datang. Oleh karena itu belajar sejarah memberikan pengalaman yang berguna bagi kehidupan kita (Aman 2011).

Proses pembelajaran di dalam kelas merupakan bagian yang sangat penting dari pendidikan. Dalam hal ini guru memiliki peran yang sangat besar dalam mengorganisasi kelas sebagai bagian dari proses pembelajaran. Pembelajaran yang bermutu diawali dari persiapan yang bermutu pula. Pembelajaran merupakan kegiatan yang dilaksanakan oleh peserta didik dan guru dengan berbagai fasilitas, materi, dan prosedur tertentu untuk mencapai tujuan yang telah dirumuskan dalam kurikulum.

Dalam pembelajaran di perguruan tinggi, khususnya Program Studi Pendidikan Sejarah, terdapat mata kuliah Sejarah Kebudayaan Indonesia. Dalam pembelajaran mata kuliah ini, sumber pembelajaran berupa buku-buku sejarah saja tidaklah cukup. Sehingga untuk memperoleh kajian yang lebih luas, sumber-sumber lain juga dapat dimanfaatkan untuk memperkaya materi pembelajaran.

\section{METODE PENELITIAN}

Bentuk penelitian ini adalah penelitian kualitatif deskriptif menggunakan strategi studi kasus tunggal. Penelitian ini dilakukan di Program Studi Pendidikan Sejarah STKIP PGRI Sidoarjo. Sumber data meliputi: (1) sumber informan, terdiri dari Ketua program Studi, dosen dan mahasiswa (2) sumber tempat dan peristiwa, dalam hal ini peristiwa, aktivitas, dan perilaku dari dosen dan mahasiswa dalam 
pembelajaran akan dilakukan Edupreneur. Capaian Pembelajaran (CP) pengamatan. dan (3) dokumentasi atau arsip, meliputi Rencana Pembelajaran Semester (RPS), Rancangan Program Perkuliahan (RPP) daftar hadir mahasiswa, jurnal perkuliahan, dan dokumen lainnya yang berhubungan dengan penelitian ini.

Penelitian ini dilakukan dengan teknik cuplikan secara purposive. Dilakukan wawancara mendalam dan observasi kepada ketua program studi, dosen dan mahasiswa. Untuk validitas data, dilakukan teknik trianggulasi yakni trianggulasi sumber dan metode. Pengolahan data hasil penelitian dilakukan dengan teknik analisis model interaktif Analisis interaktif meliputi: 1) pengumpulan data; 2) reduksi data; 3) sajian data; 4) verifikasi atau menarik kesimpulan (Sutopo 2006).

\section{HASIL DAN PEMBAHASAN}

Kurikulum yang digunakan di Program Studi Pendidikan Sejarah STKIP PGRI Sidoarjo adalah kurikulum program studi pendidikan sejarah berbasis Kerangka Kualifikasi Nasional Indonesia (KKNI) dan Standar Nasional Pendidikan Tinggi (SNPT). Profil lulusan Program Studi Pendidikan Sejarah adalah (1) Pendidik Sejarah (2) Peneliti (3) yang ditetapkan berdasarkan pada: (1) Capaian Pembelajaran khusus yang ditetapkan oleh Asosiasi/Forum Prodi, (2) Capaian Pembelajaran Penciri Perguruan Tinggi yang ditetapkan oleh perguruan tinggi sendiri dan Capaian Pembelajaran umum yang sudah ditetapkan pada Standar Nasional Pendidikan Tinggi (SNPT).

Dalam mata kuliah Sejarah Kebudayaan Indonesia, perencanaan pembelajaran diawali dengan menyiapkan perangkat pembelajaran yang meliputi rencana pembelajaran semester (RPS) dan rancangan program perkuliahan (RPP). Penyusunan perencanaan pembelajaran disesuaikan dengan capaian pembelajaran (CP) mata kuliah. Capaian pembelajaran (CP) mata kuliah selanjutnya dijadikan dasar sebagai penyusunan analisis instruksional. Capaian pembelajaran (CP) mata kuliah Sejarah Kebudayaan Indonesia adalah mampu berpikir kritis, ilmiah, berwawasan luas, etis, memiliki kepekaan dan empati sosial, memiliki jati diri sebagai bangsa Indonesia yang cerdas dan berkarakter. Secara khusus dokumen yang dianalisis dalam penelitian ini adalah RPP pada kemampuan akhir yang diharapkan yaitu mahasiswa mampu memahami konsep dasar kebudayaan. 
Pada kemampuan akhir yang diharapkan ini rencananya pembelajaran Sejarah Kebudayaan Indonesia melalui media audio visual berbasis kearifan lokal dilaksanakan. Berdasarkan hasil analisis dokumen pada RPP, ada temuan mengenai model pembelajaran sejarah yang dilaksanakan. Pembelajaran sejarah tidak menggunakan ceramah sebagai satu-satunya metode yang digunakan untuk menyampaikan materi pembelajaran. Mahasiswa lebih sering diajak untuk mengumpulkan informasi sebanyak-banyaknya dari berbagai sumber belajar, setelah itu mahasiswa diminta melakukan presentasi, diskusi, dan mengungkapkan pendapat maupun hasil analisisnya terhadap suatu peristiwa sejarah.

Sebelum pelaksanaan pembelajaran dosen menyiapkan media pembelajaran sesuai dengan materi atau pokok bahasan yang akan disampaikan. Dalam hal ini media yang akan digunakan adalah video Museum Towulan. Metode pembelajaran yang akan digunakan dalam pembelajaran ini adalah ceramah dan diskusi. Sedangkan evaluasi yang direncanakan berupa penilaian diskusi dan hasil penugasan.

Pembelajaran sebagai suatu aktifitas mengorganisasi atau mengatur lingkungan sebaik-baiknya dan menghubungkannya dengan anak didik sehingga terjadi proses belajar (Nasution 2005). Lingkungan dalam pengertian ini tidak hanya ruang belajar, tetapi juga meliputi guru, alat peraga, perpustakaan, laboratorium, dan sebagainya yang relevan dengan kegiatan belajar.

Pembelajaran merupakan kegiatan yang dilakukan secara sadar dan sengaja untuk membantu peserta didik agar memperoleh pengalaman. Maka dengan pengalaman itu tingkah laku peserta didik bertambah baik dari segi kuantitas maupun kualitas. Tingkah laku tersebut meliputi pengetahuan, keterampilan dan nilai atau norma yang berfungsi sebagai pengendali sikap dan perilaku peserta didik (Darsono 2000).

Pelaksanaan pembelajaran Sejarah Kebudayaan Indonesia melalui media audio visual berbasis kearifan lokal selesai dalam dua kali pertemuan. Pelaksanaan pembelajaran pada pertemuan pertama membahas mengenai pengertian, unsur-unsur dan wujud-wujud kebudayaan. Dosen menggunakan media video Museum Trowulan dengan metode ceramah dan diskusi.

Berdasarkan data observasi, sebelum memulai pembelajaran dosen mempersiapkan media pembelajaran 
berupa Laptop dan LCD yang dibantu oleh seorang mahasiswa yang ada di kelas tersebut. Setelah media pembelajaran disiapkan, pada kegiatan pendahuluan dosen membuka pelajaran dengan salam, memeriksa kehadiran mahasiswa. Setelah memeriksa kehadiran mahasiswa, selanjutnya dosen menyampaikan materi pembelajaran. Setelah menyampaikan materi dengan ceramah, selanjutnya dosen menayangkan media pembelajaran yang telah dibuat yakni menampilkan contoh-contoh koleksi yang ada di Museum Trowulan sesuai dengan materi pembelajaran yang sedang dibahas. Pada pertemuan ini dosen juga memberikan tugas kelompok dengan penugasan membuat media audio visual dengan tema benda/bangunan bersejarah hasil kebudayaan kearifan lokal Sidoarjo.

Penerapan model belajar dengan penggunaan media pembelajaran dapat meningkatkan minat dan prestasi peserta didik (Wibowo dan Suprapto 2020). Sehingga dapat simpulkan bahwa pemanfaatan benda bersejarah sebagai media sangat membantu dalam pembelajaran. Karena pemanfaatan benda bersejarah berbasis kearifan lokal dapat meningkatkan minat belajar dan pemahaman warisan kebudayaan yang ditinggalkan dari para pendahulunya.
Pembelajaran sejarah dapat diartikan sebagai suatu proses pentransferan nilainilai luhur dari peristiwa-peristiwa masa lampau kepada siswa melalui kegiatan belajar-mengajar. Peristiwa masa lampau tersebut mencakup hal-hal yang dipikirkan, dikatakan, dikerjakan, dirasakan, dan dialami oleh setiap manusia (Kuntowijoyo 1995).

Pertemuan kedua mahasiswa menampilkan hasil penugasan yang diberikan pada pertemuan sebelumnya. Kelompok pertama menampilkan media audio visual bangunan bersejarah Candi Pari dan mendiskusikannya. Kelompok kedua menampilkan media bangunan bersejarah Candi Tawang alun dan mendiskusikannya. Dalam pertemuan ini, kegiatan pembelajaran terdiri dari tiga tahapan kegiatan yaitu: kegiatan awal, kegiatan inti, dan kegiatan akhir yang merupakan kegiatan penutup dari proses kegiatan pembelajaran terdiri dari tahap refleksi dan penarikan kesimpulan.

Dalam kegiatan diskusi terlihat mahasiswa antusias menyimak media yang ditampilkan. Kerjasama antar mahasiswa terlihat yakni ketika siswa dituntut untuk memberikan jawaban atas pertanyaan dari kelompok yang lain. Dalam hal ini nampak bahwa melalui media audio visual membuat membuat 
mahasiswa aktif berinteraksi dalam kegiatan pembelajaran.

Pembelajaran adalah kegiatan guru secara terprogram dalam desain intruksional, untuk membuat siswa belajar secara aktif, yang menekankan pada penyediaan sumber belajar (Sudjana 2010). Dengan perencanaan yang baik, serta penggunaan media pembelajaran, maka hal yang bersifat abstrak bisa menjadi lebih konkret. Sehingga capaian pembelajaran yang direncanakan dapat tercapai.

Evaluasi pembelajaran yang dilakukan yaitu dengan penilaian berupa penilaian diskusi dan penilaian hasil penugasan. Penilaian diskusi merupakan penilaian yang dilakukan dengan mengamati kegiatan mahasiswa pada saat melakukan diskusi, dalam hal ini adalah penilaian terhadap keaktifan mahasiswa, kerjasama dengan mahasiswa lainnya dan sikap menghargai pendapat orang lain pada saat kegiatan diskusi. Sedangkan penilaian penugasan merupakan kegiatan penilaian terhadap suatu tugas yang harus diselesaikan dalam waktu tertentu, dalam hal ini tugas tersebut berupa penugasan dalam pembuatan media. Pada aspek evaluasi, dosen telah menerapkan model penilaian yang digunakan untuk mengetahui tingkat pencapaian belajar mahasiswa dan kemajuan mereka dalam pembelajaran.

Evaluasi dalam pembelajaran dimaksudkan untuk mengetahui hasil pembelajaran yang dilaksanakan dan diharapkan mampu memperbaiki pembelajaran kedepannya. Bahwa penilaian merupakan proses pengumpulan dan pengolahan informasi untuk mengukur pencapaian hasil belajar peserta didik (Ngalim 2006).

\section{SIMPULAN}

Berdasarkan hasil penelitian dan pembahasan yang telah dilakukan, maka dapat disimpulkan bahwa perencanaan pembelajaran dimulai dengan menyusun perangkat pembelajaran meliputi Rencana Pembelajaran Semester (RPS) dan Rancangan Program Perkuliahan (RPP) serta menyiapkan media pembelajaran. Sehingga pembelajaran dapat teratur dan terarah dengan baik sesuai capaian pembelajaran.

Pelaksanaan pembelajaran dilakukan dalam dua kali pertemuan. Pertemuan pertama dengan penyampaian materi pembelajaran dan pemberian penugasan membuat media audio visual berbasis kearifan lokal. Pertemuan kedua dilakukan presentasi media yang 
ditugaskan pada pertemuan sebelumnya dan dilanjutkan diskusi. Pemanfaatan benda bersejarah berbasis kearifan lokal mampu meningkatkan pemahaman mahasiswa tentang tradisi dan warisan dari pendahulunya.

Evaluasi pembelajaran meliputi penilaian diskusi dan penilaian hasil penugasan membuat media. Penilaian diskusi merupakan penilaian yang dilakukan dengan mengamati saat melakukan diskusi, meliputi penilaian keaktifan mahasiswa, kerjasama dan sikap menghargai pendapat orang lain. Sedangkan penilaian penugasan merupakan kegiatan penilaian terhadap penugasan dalam pembuatan media.

\section{DAFTAR PUSTAKA}

Aman. Model Evaluasi Pembelajaran Sejarah. Yogyakarta: Ombak, 2011.

Daliman. Metode Penelitian Sejarah. Yogyakarta: Ombak, 2012.

Darsono. Belajar dan Pembelajaran. Semarang: CV. IKIP Semarang Press, 2000.

Kuntowijoyo. Pengantar Ilmu Sejarah, Edisi Ketiga. Yogyakarta: Yayasan Bentang Budaya, 1995.

Nasution. Berbagai Pendekatan Dalam Proses Belajar dan Mengajar. Jakarta: PT Bumi Aksara, 2005.

Ngalim, Purwanto. Prinsip-Prinsip dan Teknik Evaluasi Pengajaran. Bandung: Remaja Rosdakarya, 2006.
Sudjana, Nana. Dasar-Dasar Proses Belajar Mengajar. Bandung: Sinar Baru, 2010.

Sutopo, HB. Metodologi Penelitian Kualitatif. Surakarta: Universitas Sebelas Maret, 2006.

Wibowo, Satrio, dan Edwin Putra Dwi Suprapto. "Meningkatkan Minat dan Prestasi Belajar Sejarah Melalui Model Grup Investigasi Dengan Media Museum Pada Siswa kelas XII IPS I SMA Katolik Untung Suropati Sidoarjo." Jurnal Ilmu Sosial dan Pendidikan, 2020: 106-109. 